総説

\title{
傾斜機能材料の現状と今後の展開
}

\author{
新野正之, 木血 且人 \\ 独立行政法人 宇宙航空研究開発機構, 干981-1525 角田市君萱字小金沢 1.
}

\section{The Present Status of the Functionally Graded Materials, and Future Prediction}

\author{
Masayuki Niino and Katsuto Kisara \\ Japan Aerospace Exploration Agency, 1 Koganezawa Kimigaya, Kakuda 981-1525.
}

Received December 24, 2003

\section{SYNOPSIS}

It has been about 20 years since the concept of functionally graded materials (FGMs) was first proposed, and the FGM study is now in the level of practical application. The FGM research developed from the national projects by the national government has spread to the commercial level, and we came to see many FGM products made by mass production methods. In this report, several major samples of FGM application technologies created by private companies are introduced. In addition, the recent development of FGM study including international collaborations and the most advanced fields of studies are discussed. The FGM Forum of Japan that has devoted for promotion of FGM technology will be reported on its role and future activities.

KEY WORDS

Functionally Graded Material, Products

\section{1 緒 产}

1986年に生じたスペースシャトル「チャレンジャー」の事 故は世界の宇宙開発に大きな衝撃を与えた。 日本においても 宇宙往還機の研究開発が開始されていた時分であり，当時旧 航空宇宙技術研究所 (NAL), 東北大学を中心に仙台在住の研 究者グループが今日傾斜機能材料と呼ばれる機能材料設計法 の概念を提唱したたことは良く知られている1).

1987 年, 旧科学技術庁は振興調整費による総合研究で宇宙 往還機用外壁材に期待できる熱応力緩和型傾斜機能材料の創 製を目的とした基盤技術研究を開始した ${ }^{2)}$. 以後，旧科学技術 庁，旧文部省，旧通産省などの予算で基礎から応用まで一連 の傾斜機能材料開発プロジェクトが実施され幅広い研究開発 がなされ，今日に至っている. Table 1 に主要なナショナルプ ロジェクトを示す.わが国で誕生した傾斜機能材料はこの間, 世界的な広がりを見せ各国において研究や実用化が進められ ている.傾斜機能材料が提唱された 1986年以降の情報を収集 した傾斜機能材料データベーズによれば1999年までに30カ 国を超える国々の研究者が国際シンポジウム等で発表してお り，傾斜機能材料データベースへのアクセスログを分析する
と傾斜機能材料は先進国のみならず，発展途上国においても すそ野を広げていることがわかる．このように傾斜機能材料 研究が世界中に普及している現状を見ることは，傾斜機能材 料を黎明期から担って来た筆者らにとって実に感慨深いもの がある。

傾斜機能材料研究の歴史はわが国の宇宙開発，特に日本版 スペースプレーンへの採用を目指して研究が進められた。字 由からの再突入時にノーズコーンや翼のリーディングエッジ などは空気との摩擦によって極めて高い空力加熱を受ける. 一方，機体内部は機器の熱防御が不可欠であり，外側は高温 に耐え内面への熱進入を抑制するとともに，宇宙器として軽 量化を兼和備えた構造材料が不可欠となる. 同時に当時ス ペースシャトルで生じていた熱応力による外壁タイル脱落の ような問題を生じさせない超耐熱材料の研究が期待されてい た.こうした多機能超耐熱材開発が最初のFGMプロジェクト の目標であり, 1991 年, $30 \mathrm{~cm} \times 30 \mathrm{~cm}$ のFGMによる外壁材が 作成されだ). 同時にノーズコーン等を想定したC/C傾斜材や 冷却構造を持つ宇宙用構造材が試作された.

本プロジェクトによる傾斜機能材料技術を用いて, 繰り返 
Table 1 Primary National FGM Projects Engaged.

\begin{tabular}{|l|l|}
\hline Term & Project \\
\hline $1988-1993$ & $\begin{array}{l}\text { FGM development for thermal stress } \\
\text { relaxation (Special Coordination Funds) }\end{array}$ \\
\hline $1993-1997$ & $\begin{array}{c}\text { Development of energy conversion materials } \\
\text { through the formation of gradient structure } \\
\text { (Special Coordination Funds) }\end{array}$ \\
\hline $1995-1997$ & $\begin{array}{l}\text { FGM development for unutilized energy } \\
\text { (Special Coordination Funds) }\end{array}$ \\
\hline $1996-1999$ & $\begin{array}{l}\text { Physics and Chemistry of FGM(Grant-in-aid } \\
\text { for Scientific Research) }\end{array}$ \\
\hline $1996-2002$ & $\begin{array}{c}\text { Japan-US collaboration on the large-size } \\
\text { FGM manufacturing technology (supported by } \\
\text { NEDO) }\end{array}$ \\
\hline $2000-2002$ & $\begin{array}{c}\text { Preparation of FGM database (supported by } \\
\text { JST) }\end{array}$ \\
\hline Since 1996 or around & \begin{tabular}{l} 
Other NEDO and JST-supported businesses \\
\hline
\end{tabular} \\
\hline
\end{tabular}

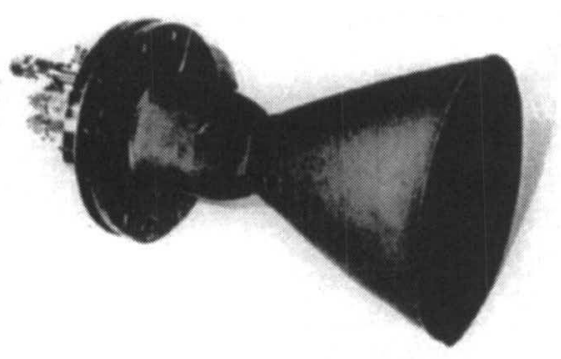

The RCS thruster used in this tests.

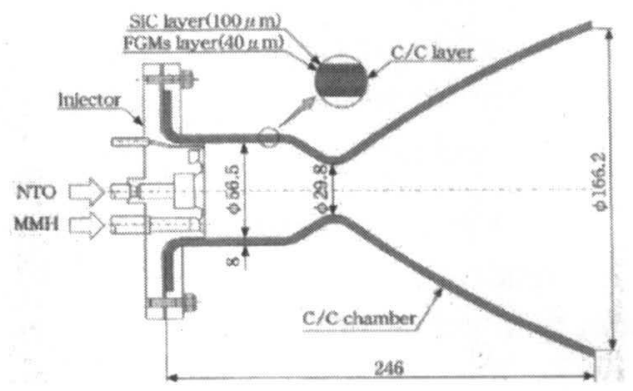

The designed thruster uses a steel injector body and a film cooled C/C-SiC FGM chamber.

Fig.1 FGM-applied Rocket Engine.

し使用が求められる HOPE 用姿勢制御 (RCS) や軌道間推進用 スラスタ (OTV)として傾斜機能材料によるエンジン研究が進 められ, C/C-SiC系材料の姿勢制御エンジン(Fig.1) 要求条件を満たす耐久性試験をクリアした. またオリエント エクスプレスへの搭載を想定した熱防御システム (TPS) は宇
宙実証試験ので実用化レベルまで到達した. しかしながら, わ が国の宇宙開発の昨今は周知のように多くの困難を抱え, 宇 宙器や衛星に先進技術である傾斜機能材料技術を宇宙実証す る余裕が無いのが現状である.

宇宙開発への傾斜機能材料採用が遅々として進展しない間 に, FGM概念は他分野への浸透が急速に進み傾斜機能材料研 究分野が広がると同時に民生品として実用化の域に達してき たものも少なくない(Fig.2). 技術立国を標榜しているわが国 の科学技術施策の一つとして, 国研や大学等で研究した成果 を産業界で活用するという方針に基づいて技術移転が樌極的 に進められ，多くのFGM製品が実用化されている. 本稿では こうした背景を踏まえ, 特に我が国における傾斜機能材料の 実用化促進や普及を中心的に担って来た傾斜機能材料研究会 の活動と合わせて紹介するとともに，筆者らの所属する文部 科学省金下の独立行政法人宇宙航空研究開発機構(JAXA)や科 学技術振興機構(JST)の実用化支援事業及び傾斜機能材料技術 の国際協力事業もふくめた新しい分野への展開についても言 及する。

\section{2 実用化の現状}

最初のプロジェクト開始から 18 年を経た今日, FGMの概念 は幅広い分野に浸透し, 傾斜機能材料(FGM) と記載している 特許は 1000 件を越え, 多くの製品が開発され商品化されてい る.こうした現状を踏まえ, FGM研究会は事業の一環として, FGMのより大きい可能性を引き出す情報交流の場を提供し実 用化を促進するためここ数年 FGMのアプリケーション技術, 民生品への応用など商品化を含めたFGM実用化を紹介する公 


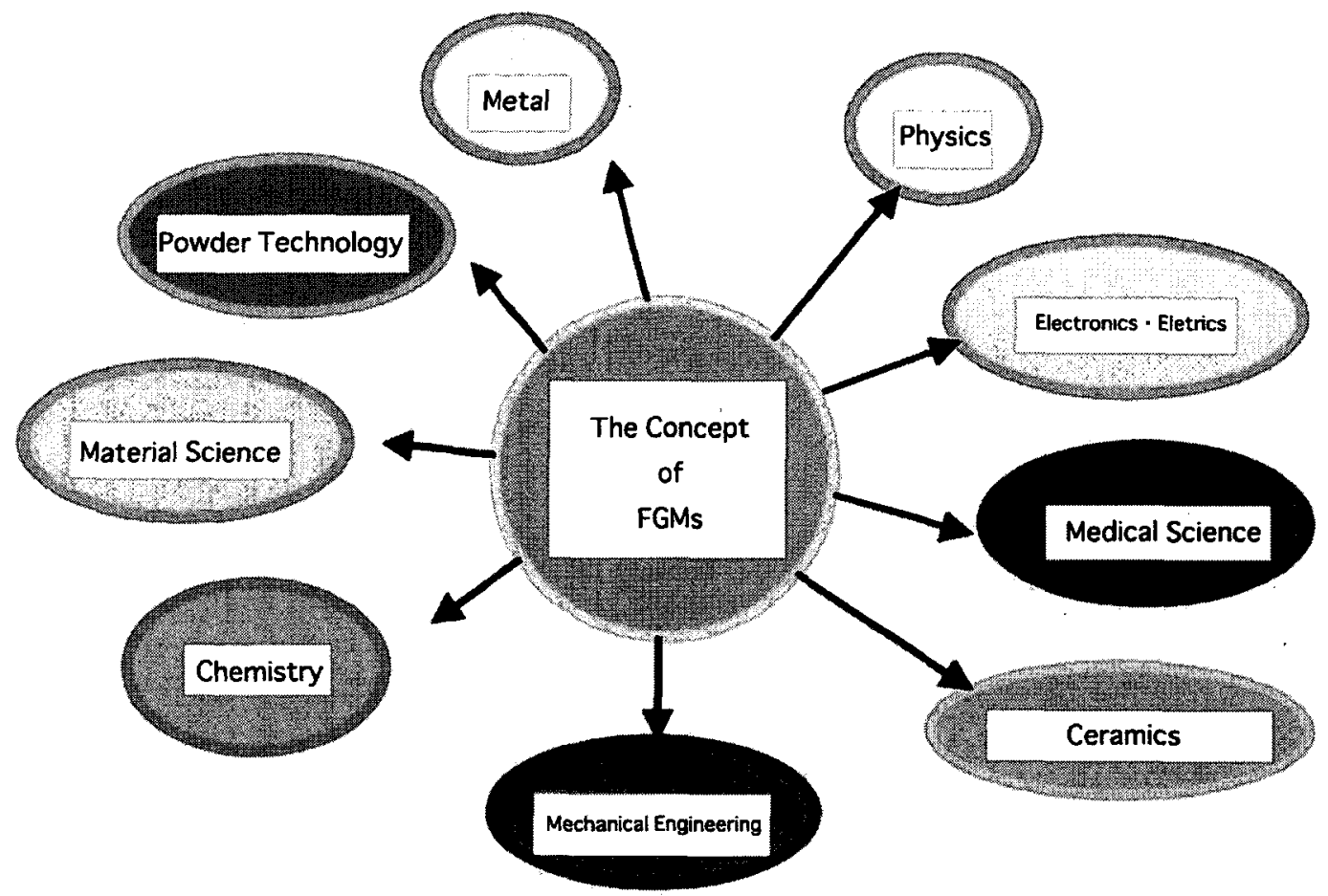

Fig.2 Other Fields of Studies that the FGM concept is applicable.

Table 2 Workshops.

\begin{tabular}{|c|l|l|}
\hline FY 2000 & $\begin{array}{l}\text { Application to commercial } \\
\text { products }\end{array}$ & $\begin{array}{l}\text { Use in cutting tools } \\
\text { Use in spikes of baseball shoe }\end{array}$ \\
\hline FY 2001 & $\begin{array}{l}\text { Application to Optical } \\
\text { Devices }\end{array}$ & $\begin{array}{l}\text { Optical fiber } \\
\text { Photonic crystal }\end{array}$ \\
\hline FY 2002 & $\begin{array}{l}\text { The 1st Workshop on the } \\
\text { Practical Application of } \\
\text { FGMs }\end{array}$ & $\begin{array}{l}\text { Electrics, Electronics, Optical } \\
\text { communication, Cutting tool, } \\
\text { Watch, Electric shaver, Baseball } \\
\text { shoe, Space development, Mass } \\
\text { production technology }\end{array}$ \\
\hline FY 2003 & $\begin{array}{l}\text { The 2nd Workshop on the } \\
\text { Practical Application of } \\
\text { FGMs }\end{array}$ & $\begin{array}{l}\text { Biology, Fiber, Coating, Steel } \\
\text { plate, Space development, Mass } \\
\text { production technology }\end{array}$ \\
\hline
\end{tabular}

開ワークショップを開催してきた. 最近のワークショップの 概要を Table 2 に，応用例を Fig.3に示す.

2001年までは研究会内部のワークショップで運営してきた が, FGMデータベースの整備と平行して実用事例の調查を進 めてきた結果, 現在までに優に 40 件の事例を数え, 2002 年か らは紹介する事例の件数が增えてきて，一般参加者に門戸を 広げた。ワークショップで紹介された実用化事例》は，超耐 熱材料, 僱熱コーティング, 工具材料, 電気・電子デバイス 分野, 人工骨, 人工歯根等の生体分野, 時計, シェイバー, ス
ポーツ用品などの生活用品, 光ファイバー, フォトニック結 晶等のオプトデバイスへの応用, 高分子分野等々実に多岐に 渡っている。こうした分野の様々な開発において，設計から 作製プロセス，特性評価，マーケティングなどについて講演 発表され，実用化ワークショップを通して異業種交流が新応 用の開拓に役立つものと確信している. 具体例として，住友 電工の超硬バイト, シチズンの時計のケースを示す.

2.1 住友電工の超硬バイト8)

バイトの表面には耐摩耗性のTiCN-Ni系のサーメット相を， 


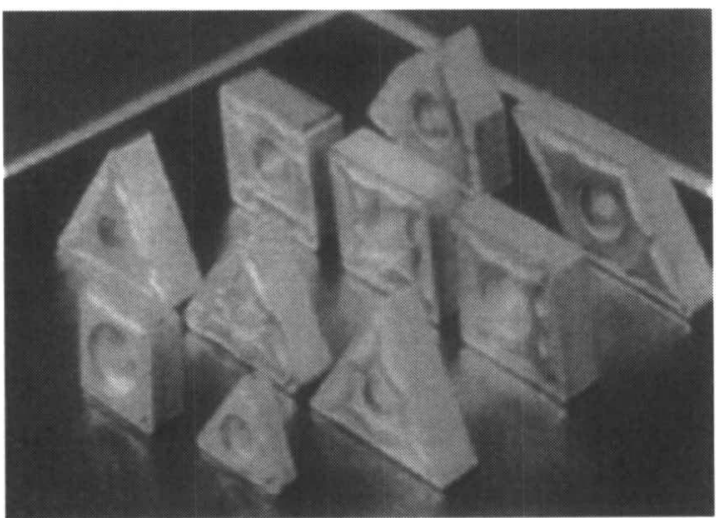

Cutting tool (Sumitomo Electronic Industries Ltd.)

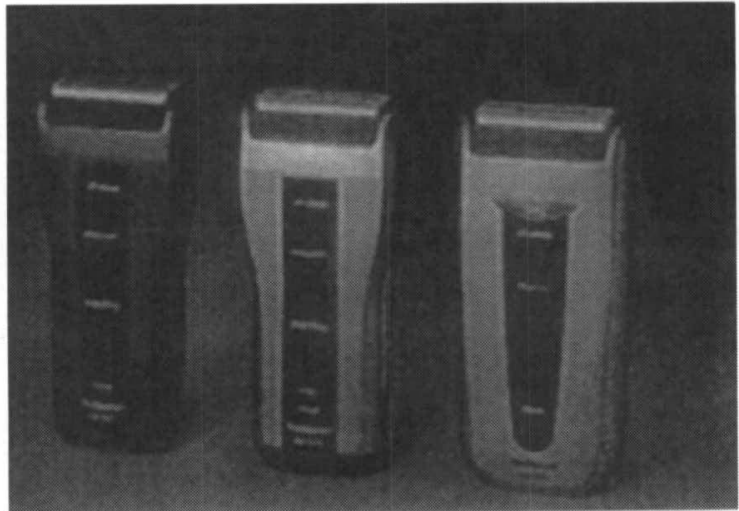

Electric Shaver (Matsushita EElectric Works, LTD)

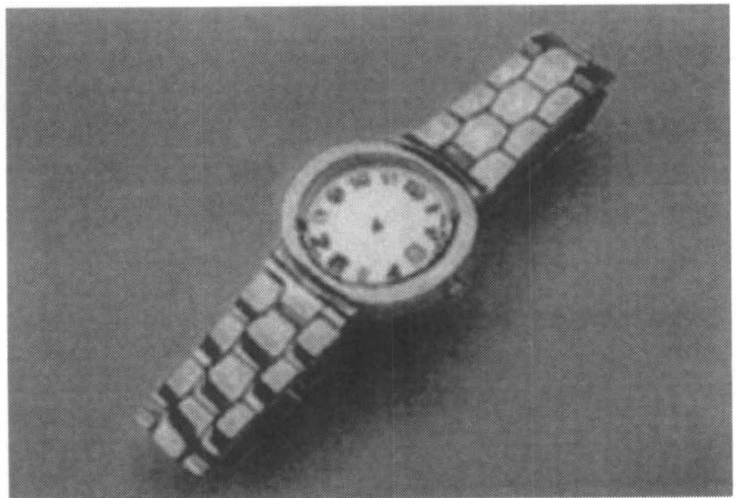

Watch (CITIZEN)

Fig.3 Application samples.

内部には勒性に優れたWC-Co系の超硬合金相を配置し, しか も表面部の熱膨張率が内部より小さくなるように組成の傾斜 化を行うことで表面に高い圧縮の残留応力を付与した(Fig.4). このように住友電工の超硬バイトは傾斜組成粉体の焼結に際 し予歪み設計の概念を取り入れ, より強勒な工具を完成させ ている，傾斜機能性を設計段階から導入した材料設計技術の 優れた一例と言える.

2.2 シチズンの「デュラテクト・チタン」表面処理 (Fig.5 .5)

表面からの深さ $20 \sim 30 \mu \mathrm{m}$ まで窒素や酸素を拡散させ, 固 溶量が多い表面は硬さが約 $1500 \mathrm{HV}$ から, 固溶量がほぼゼロ

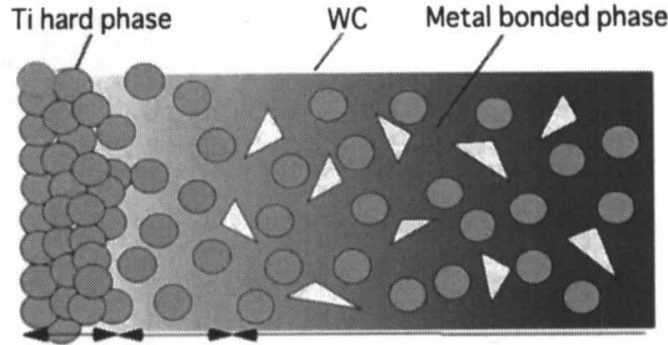

Ceramic layer Graded composition part Carbide composition

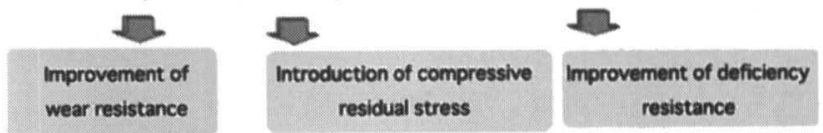

Fig.4 FGM Sample of Sumitomo Electric Industries.

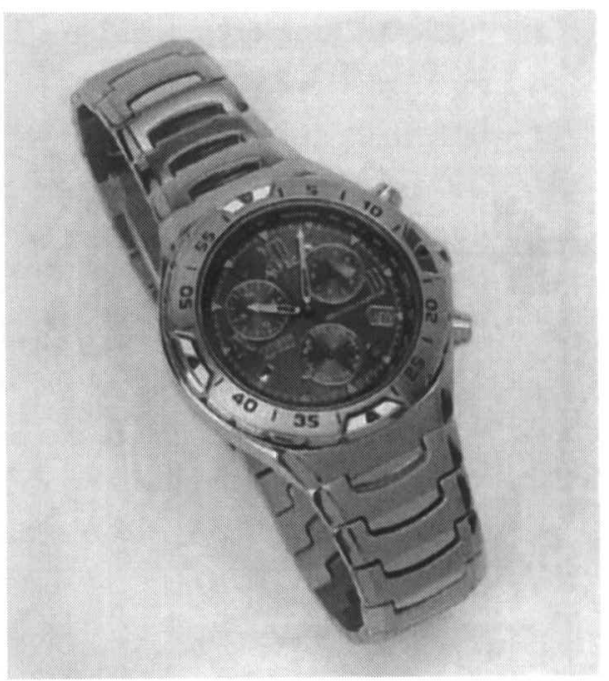

Fig.5 FGM sample of CITIZEN.

の深さ $30 \mu \mathrm{m}$ では硬さがチタンの元々の硬さの $170 \mathrm{HV}$ まで連 続的に減少している. 傾斜機能になっているので, 表面硬化 層が剥離(はくり)しにくくなっており,この技術は腕時計の ベゼル，バンドなどの外装部品で採用されている．この製品 化事例は窒素雾囲気での拡散現象を巧みに利用して安価な製 造法を製品化に繋げた例として価値がある.

\section{3 低コスト, 量産製法の確立}

製造法について注目してみると, NEDOが一貫して進めて きたプラズマ焼結法 ${ }^{10}(\mathrm{SPS})$ は粉末焼結法による FGM 製造法 として大いに期待できる手法である，それは製造原理に起因 しており, カーボンダイスの形状を最適設計することで, 短 い距離で大きな温度差を保持した環境下で瞬時に焼結を達成 出来る点にある，プラズマ焼結法は，高生産性の鍵といわれ る連続法が開発され，超硬工具，ノズル，金型製造等の種々 の製品化が進んでいる (Fig.6). 特に最近, 北海道工業試験所 で開発が進められた (Fig.7)，超硬材料と Ni の段階的 FGM を 


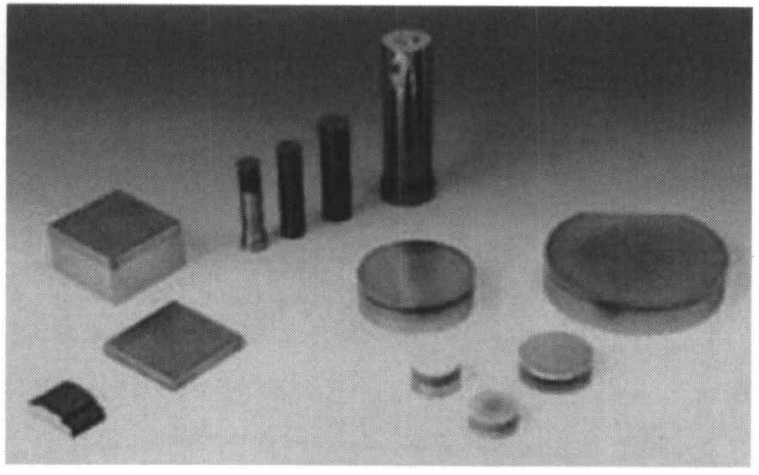

Fig.6 SPS Products Samples.

用いた腐食性流体の搬送用スクリュー ${ }^{11}$ への適応はSPS の市 場展開の見本になりうる. $\mathrm{Ni}-\mathrm{Co}$ 系超硬部分は耐腐食性スク リュー面を構成し， $\mathrm{Ni}$ 部分は溶接部位を提供する. しかも焼 結体は設計コードを基にニアネットシェイプ製品として完成 しておりSPSの特徴を旨く生かしている.

またスラリー遠心分離法に凍結乾燥法を採用した製造法 ${ }^{12}$ はJAXA，JST資金で技術移転が進められており熱応力緩和型 FGMの製造技術の低コスト化及び製品開発を主目的としてい る. 具体的にはJAXAの技術移転プロジェクトではIH加熱製 品の開発 ${ }^{13)}$, JSTの独創的モデル化事業では反応容器部材への FGMの適用を目的としている. Fig. 8 は IH ヒーターに適応を 目指したポット，土鍋の例を示す．金属部が電磁加熱ヒー ターとして働く．さらにJAXA はこれら一連の技術移転プロ ジェクトを通して遠心分離法とSPS を組み合わせることによ り FGMの低コスト，大量生産技術の確立を目指している.

\section{4 知的財産の整備と戦略}

これらの実用化の動きと連動し進んできたものに知的財産 の整備が上げられる．知的財産戦略，材料の標準化等はこれ まで欧米に主導権を握られてきた分野であるが，我が国が リードしてきた傾斜機能材料研究成果の活用については是非 日本が世界をリードして行って欲しい分野である. 傾斜機能 材料研究成果を広く活用する手段として一連のナショナルプ ロジェクトの成果を含め内外のFGM関連研究成果を網羅した 傾斜機能材料データベースを整備開発した (2002 年 10 月に公 開運用).このデータベースは旧航空宇宙技術研究所 (現 JAXA)が，JST の資金協力を得，1986 年以降の傾斜機能材料 プロジエクト情報を中心に内外の 1300 の研究論文を整理分類 し, 日本語と英語で情報をまとめWEB上に公開しているもの で，無料で情報を活用できる．ここ一年間の利用実績を分析 した結果を表に示す. 海外からのアクセス機関は国際FGMシ ンポで見られる研究機関以外にも更に多くの機関へと広がっ ていることが分かる. 特に中国を中心にしたアジア圈の関心 は高いようで,アクセスにもそうした現状が反映されている. 国内からのアクセスは民間のアクセスが大半であり, 実用化 の動きと呼応しているものと思われる.

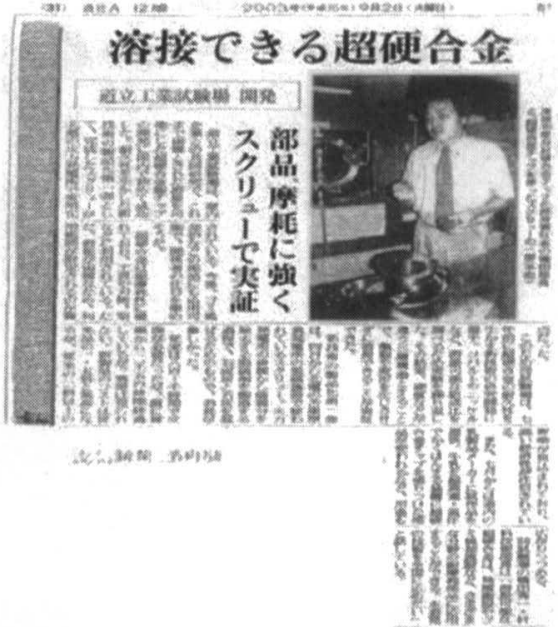

- Place where FGM was applied.

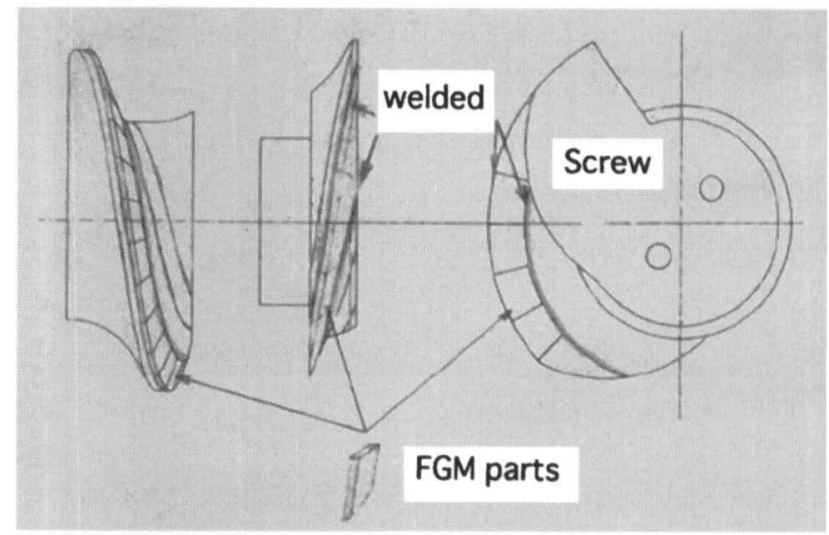

FGM was replaced to the steel product with heavy wearing

- The FGM screw was built into the extruder below and tested.

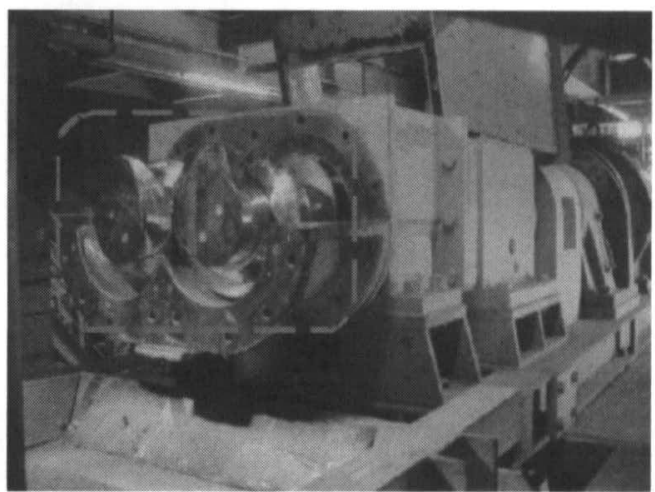

The operating time has been reached near 3000 hours. (which used to be about 1000 hours)

Fig.7 Sample of Hokkaido Industrial Research Institute.

また新しい技術において規格化の主導権を取ることは重要 な戦略の1つであり, NEDO でも FGM・JIS 化委員会活動 ${ }^{14)}$ が 進められており,これらの実用化の動きと連動しており頼も 


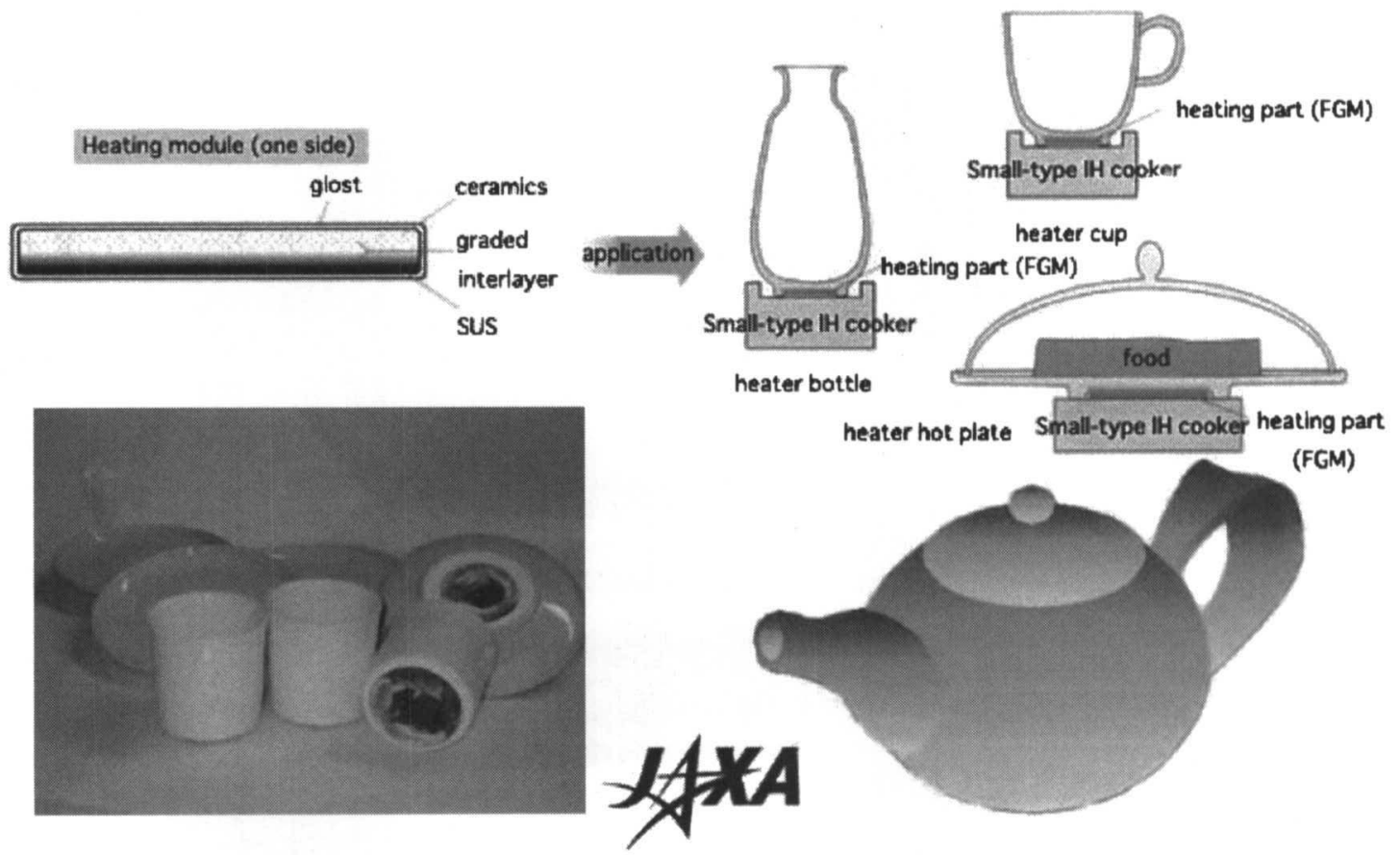

Fig.8 IH heater products.

しい限りであるが, 最近の例として光触媒分野で日本が実用化 で先行していながら,国際的には欧米から外堀を埋められかね ない事例がある. 特に我が国優位の FGMに関しては是非 ISO 化までを視野にいれ活動を展開し同じ徹を踏まないで欲しいも のである.傾斜機能材料技術は技術立国を標榜している我が国 の国際戦略の一つになりうるものである.

\section{5 国際協力}

一方, より広い立場での国際戦略として国際協力がある. 国 際的活動としては日中協力が JAXA, JAST (航空宇宙技術振興 財団), 東北大が中心になり武漢理工大他との間で FGMによ る環境低負荷技術協力を主眼に交流を進めている.特に中国側 パートナーの武漢理工大は武漢が中国西部開発の拠点であるこ とから, 西部地域約3億人の住民を対象にした分散型電力の開 発に力を入れている. 傾斜機能材料プロジェクトのアプリケー ション技術として研究を進めている途上で特許化した太陽光熱 複合発電システム(旧NAL特許) ${ }^{15}$ )を共通のプロジェクト目標 としている. 中国では平成 15 年 1 月から 4 年間 5,000 万円 (中 国の物価を勘案すると約 20 倍の価値がある) の巨費を投じて 太陽光熱複合発電の研究開発がスタートさせた. 中国との経済 協調は今後の我が国の経済を論ずる上で無視しては通れない し, また環境問題も然りである.その意味で本プロジェクトの 持つ意義は大きい.より広範なFGM研究会での国際活動とし ては 2 年に 1 度の FGM 国際会議を継続開催しており,ここで もドイツ, 米国, フィンランド等からの実用化の発表が見られ るようになっているがやはり, FGM 発祥の地である日本の実 用化が先行している.

\section{6 今後の展望}

6.1 新しい国の材料開発の指針

将来展望であるが, 最近発表された総合科学技術会議で策 定された国の材料開発の指針によると，研究開発に際し府省 間の壁を取り除く政策が促進される方向にあり分野領域を越 えた連携が進むであろう. 生体材料はこれまで材料研究を医 療の現場に採用しようとすると大きな壁があった. 少ない経 験ではあるがFGM 日中ワークショップで実感したことは FGMの研究では後発国の中国で現場へ応用が早いということ である. しかしこれからの高齢化が進む中で人工骨や人工歯 根などの生体分野は医療現場での早期の適応を目指して開発 を進めなければならない重要な分野である. 生体材料研究は まさにフォローの風を受ける絶好の機会にある. 生体は傾斜 機能で出来ているといっても過言ではない. 生体材料はFGM の原点であり，あえて人工の生体材料に回帰しようとするも のでありFGMを適応した人工歯根の研究は将に成熟の域に達 している. Fig.9にはその一例を示す.

また技術立国日本を目差す我が国において，島津製作所の 田中さんがノーベル賞を受賞した計測技術や検出器などの材 料システムの開発支援にも重点が置かれる傾向にある.この 分野はFGM概念がまさに得意とする「使用環境に応じて設計 が先行し, 組成, 組織の傾斜化を制御する, というシステム 設計概念」の材料技術である. まさにFGMの本領を発揮出来 る新分野になると期待している.

6.2 宇宙太陽発電に要求される革新的材料技術

傾斜機能材料の誕生は宇宙開発への適用がきっかけであっ たが，今日でも傾斜機能材料技術は先端科学技術として文科 
: Titanium powder $\mathrm{O}:$ Apatite powder

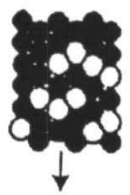

Filling
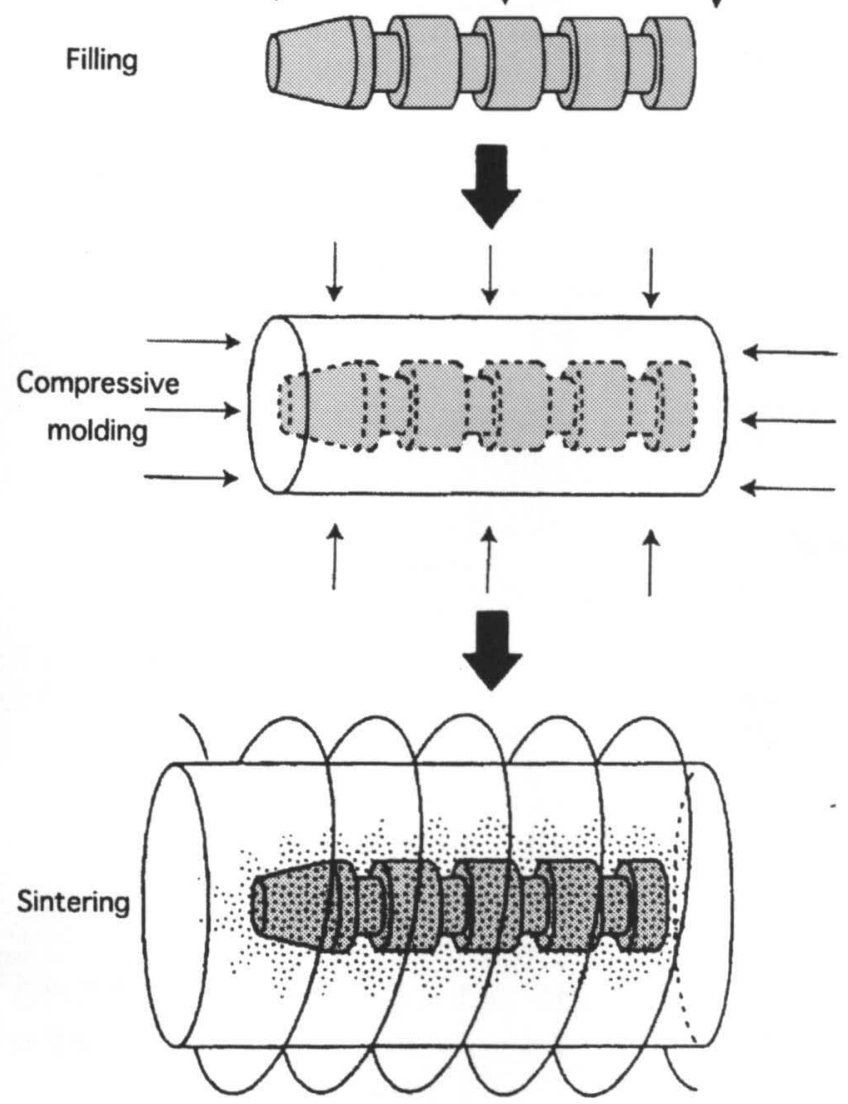

Fig.9 Overview and cross sectional surface of the Ti/20\% HAP FGM dental implant.

省JAXA，経産省 USEF (無人宇宙利用) で研究が開始された 宇宙太陽発電所を構築する場合の不可欠な要素技術である. 恒久的なエネルギー源を宇宙に求めようとする野心的構想で あるが，そこでは超軽量, 高効率エネルギ一変換素子, 高機 能材料開発など多くの開発が待たれている. SSPS と略称され ている宇宙太陽光発電システムの概念 ${ }^{16}$ (Fig.10) を紹介する と, 現在文科省JAXA, 経産省 USEFでは 20 年〜 30 年後の実 用化を目指し, 宇宙太陽発電システムの検討を開始している. しかし現状の技術で見積もると太陽発電所の重量が数万トン となり, 宇宙輸送コストが膨大になり, 経済性の観点から成 立性が相当厳しくなる. これを解決するためにエネルギ一変 換効率の飛躍的向上と材料の超軽量化が求められている. FGM の概念, ナノ技術の積極的採用が鍵であろうと思われ る. そこではFGMパート2(エネルギー変換型FGM プロジエ クト $)^{17)}$ で手がけた熱電発電, 熱電子発電, 宇宙放熱材, 太陽 電池, 光分離フィルター等の成果, さらにFGMの概念を発展 させた太陽光励起レーザー素子, レーザーから水素を発生す

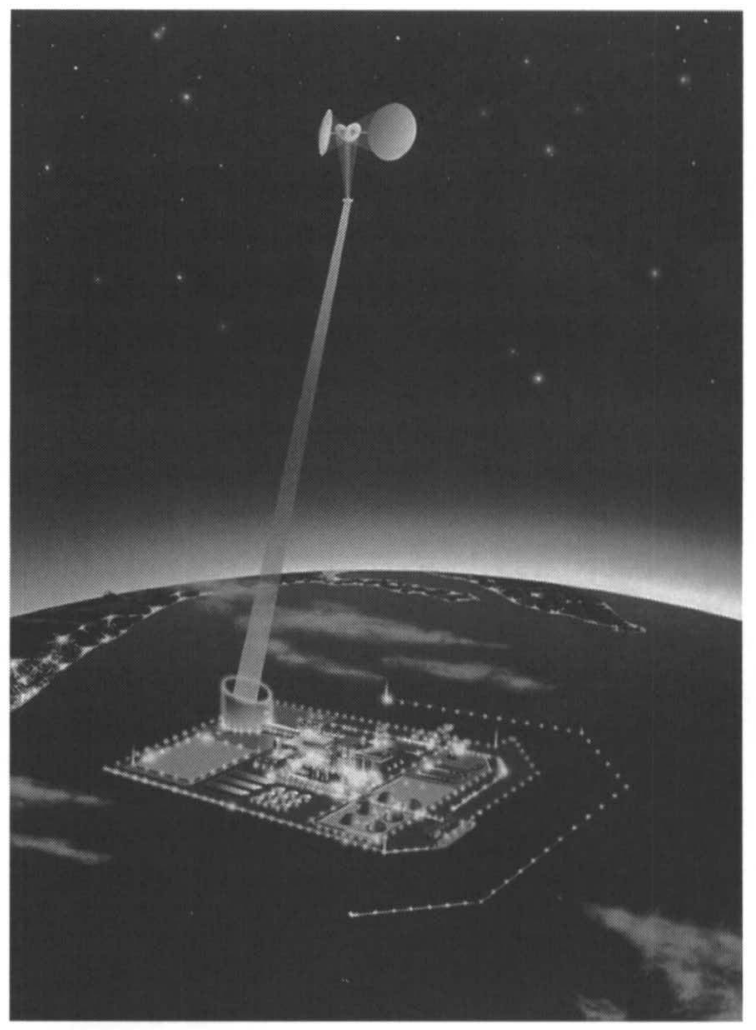

Fig.10 The Concept of SSPS.

る光触媒，ペルチエ素子によるヒートポンプ素子，高分子薄 膜等と多岐に渡る先進FGMの出現が期待される. 傾斜機能材 料研究会 (平成 16 年 4 月から事務局・航空宇宙技術振興財団) ではこれらの材料創製に関する調査を平成16年度から開始す る予定である.

\section{7 結 言}

われわれ日本人は, 古来より自然から学び, 自然を良く観 察してきた. 我が国の匠の技術は, 自然を読み, 自然を活か しながら技術を向上させてきた，有史以来，伝統的技術の一 つである鍛冶の技術もそうした伝統的工芸であるが，この技 術はまさに傾斜機能材料創製技術である. 日本刀は傾斜機能 であり，刀鍛冶がたたき上げた匠の工芸品である．優秀な刀 鍛冶が種子島に伝来した鉄砲を短時間のうちに技術を吸収向 上させ, 数十年で世界最大の火器製造大国になったことは日 本人の技術者に流れる伝統的匠の心であろう. 現代において 傾斜機能材料技術は従来の高い技術を基礎に飛躍的に技術革 新できる技法と言える.

一様性を旨とした材料分野で, 敢えて斜めに発想を変えて 見る, それがFGMの真骨頂である. 今, 新しい発想が求めら れる時代に, FGMの役割は益々重要になっている.

本稿を終えるに際し改めて要約すると

(1) 傾斜機能材料技術の多くの分野への浸透

(2) 低コスト, 高生産性をもつ生産技術の発展 
(3) 国際協調と国際戦略

(4) 新たな機能を創出する基礎研究の充実

(5) 世界中の FGM 情報の整備と発信

これら5つのキーワードが傾斜機能材料研究会を軸に旨く循 環し始めた。傾斜譏能材料研究会が普及促進の役割を担い, 匠の技術で世界をリードするならば，日本の製造業の再活性 化に少なからず貢献できるであろうと確信する.

\section{文献}

1) Nino, Watanabe, Ikeuchi, Sata and Hirai: "The beginning of FGM concept", New Ceramics, 2(5)(1989)33-37.

2) Reports on the investigation in the FY 1996 Special Coordination Funds for Promoting Science and Technology, Research and Development Bureau of the Science and Technology Agency, March 1987.

3) Kisara: "Functionally Graded Materials Database", CHEMICAL INDUSTRY, 54(11)(2003)7-12.

4) Special Coordination Funds for Promoting Science and Technology, "The research on the generic technology of FGM development for thermal stress relaxation", Achievement Report for the FGM Part II., February 1992, Research and Development Bureau of the Science and Technology Agency.

5) A.Kumakawa and M.Niino: "Ceramic coatings", ASME MD, 44(1993)197-208.

6) N.Kiuchi, et.al: "Results of High Performance Material Experiment (HIPMEX) on C/C composites with SiC/C-FGM coating", Proceedings of FGM'97, (1997)95-100.

7) Uemura, Noda, Shinohara and Watanabe: Development and Application of Functionally Graded Materials, CMC Publishing Co. Ltd., (2003).

8) Uemura, Noda, Shinohara and Watanabe: Development and
Application of Functionally Graded Materials, CMC Publishing Co. Ltd., (2003)286-296.

9) Uemura, Noda, Shinohara and Watanabe: Development and Application of Functionally Graded Materials, CMC Publishing Co. Ltd., (2003)332-337.

10) Uemura, Noda, Shinohara and Watanabe: Development and Application of Functionally Graded Materials, CMC Publishing Co. Ltd., (2003)50-60.

11) Kamota, et.al.: "Deveropment and Application of Graded Ni based Super Alloy", Proc. of FGM 2003, Waiting for printing, (to be published in 2004).

12) Uemura, Noda, Shinohara and Watanabe: Development and Application of Functionally Graded Materials, CMC Publishing Co. Ltd., (2003)62-66.

13) Kisara, Niino and Noguchi: "Technology of FGMs manufacturing at low cost", Proc. of FGM 2003, Waiting for printing, (to be published in 2004).

14) A.Kawasaki, Y.S.Kang and R.Watanabe: "Standardization of testing and evaluation method for heatresistance of functionally graded materials", Abstracts of Autumn meeting of JSPM, 2003, Osaka University, Japan, (2003)28.

15) Niino and Kisara: "Hybrid Generation System of Solar Photon and Thermal Energy", Patent No.186643, (November, 1997).

16) Mori, et.al.: "Meeting of FGM with Solar Energy and Laser Power", Proc. of FGM 2002, (2002)152-170.

17) Special Coordination Funds for Promoting Science and Technology, "Research project on the development of energy conversion materials through the formation of gradient structures", Achievement Report for FGM Part I, Research and Development Bureau of the Science and Technology Agency, (February 1997). 